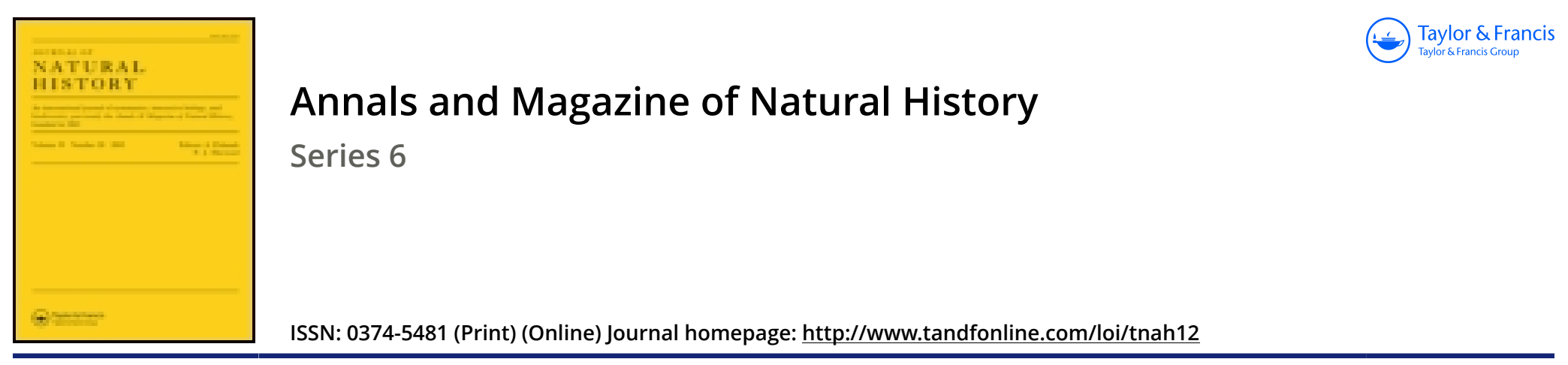

\title{
On the development of the branchial pouches and aortic arches in marine turtles, from investigations upon embryos of Chelonia viridis
}

\section{Dr. J.F. van Bemmelen}

To cite this article: Dr. J.F. van Bemmelen (1893) On the development of the branchial pouches and aortic arches in marine turtles, from investigations upon embryos of Chelonia viridis, Annals and Magazine of Natural History, 12:72, 477-478, DOI: $10.1080 / 00222939308677657$

To link to this article: http://dx.doi.org/10.1080/00222939308677657

Published online: 06 Oct 2009.

Submit your article to this journal $\sqsubset$

Џll Article views: 3

Q View related articles $\square$ 
On the Development of the Branetial Pouches and Aortic Arches in Marine Turtles, from Investigations upon Embryos of Chelonia viridis. By Dr. J. F. van Benyelen, of Batavia.

1. The earliest rudiments of the branchial pouches and aortic arches in turtles entirely agree with those found in lizards and snakes; their subsequent devclopment, however, pursues a different course, and is more in accordanco with tho conditions observed in birds than with those exhibited in the case of the other reptiles.

2. As in the last-mentioned animals, the rudiments of five branchial pouches and six aortic arches are primitively formed. Besides these, on the posterior wall of the hindermost branchial pouches, where the branchial section of the gut narrows to form the pharyngeal portion, an additional pair of pouch-shaped evaginations are developed, just as the same process takes place in snakes. They lie to the right and left in the region in question, where in lizards there arises on one side only, namely on the left, an epithelial evagination, which becomes constricted off in the form of a vesicle previously termed by me the "supra-pericardial body" ("Suprapericardialkörperehen"), since I regard it as homologous with the derivatives of the branchial gut in the Selachians, upon which I bestowed the same designation.

3. The three foremost branchial pouches are undoubtedly open during a short time. Whether this is also the case with regard to the two hindermost ones I cannot definitely say, but it appears to me to be probable with respect to the fourth branchial pouch.

4. As in the Amniota, the tuba Enstachii arises from the dorsal portion of the first branchial ponch ; its external aperture soon closes again, while the tympanic carity does not develop until much later.

5. The second branchial pouch lies close behind the first; the portion of the branchial gut separating the one from the other possesses a wider lumen than the section following further towards the rear. The dorsal apex of the second branchial pouch expands into a follicle-shaped epithelial bud; this, however, does not become constricted off, as in the case of the lizards, where it forms the first (foremost) lobe of the thymus. Neither does the sccond branchial cleft become entirely constricted off from the branchial gut, to remain as an epithelial vesicle lying in the midst of the connective tissue of the neck, as in the case of the snakes. In the subsequent development of the embryo the second branchial pouch simply becomes aborted, as in the birds.

6. The cleft-shaped external apertures of the foremost branchial pouches undergo, as in the case of birds, a considerable backward movement. This shifting of position is occasioned by the backward outgrowth of the branchial arches, which consequently commence to cover one another in imbricated fashion. The second branchial cleft in particular undergoes so much backward displacement that the corresponding branchial pouch becomes greatly elongated in the 
form of a tube. This tube persists until the later stages of development, and grows in length with the whole cervical region without increasing in circumference, so that it finally constitutes a long, thin, caudally directed, cervical, fistulous canal. In young developmental stages of snakes and lizards we certainly meet with a similar canal in a rudimentary condition; in these forms, however, it undergoes no further development, but disappears much earlier.

7. The third branchial pouch swells out into an epithelial follicle, with many secondary evaginations. This becomes constricted off from the branchial gut, and the evaginations transform themselves into thymus-tissue, in the interior of which, however, the central epithelial follicle persists. The latter may be regarded as the homologue of the carotid body in the lizards.

8. The fourth and fifth branchial pouches develop jointly with the above-montioned supra-pericardial evaginations from a lateral cæcum-shaped fold at the posterior end of the branchial gut (recessus precervicalis), similarly to what is found to be the case in snakes. They soon become entirely constricted off from the branchial gut, and in this manner form a complex of three epithelial vesicles in connexion one with the other. Now, if their further development also takes place on the same lines as in the snakes, the two foremost of these vesicles, which represent the remnants of the fourth and fifth branchial pouches, should develop into thymus-tissue, while the third and hindermost should, on the contrary, remain in an epithelial condition. This, however, is not the case: all three retain an epithelial character, and are met with in this shape, even in much later developmental stages, between the aortic and pulmonary arches. They do not come into connexion with the thyroid.

9. The aorta develops from the artery of the fourth branchial arch, the pulmonary artery from that of the sixth. The fifth aortic arch, the rudimont of which arises between the fourth and fifth branchial pouches, very soon becomes aborted again, as $I$ have also shown to be the case in snakes and lizards.

10. The observations here detailed confirm the theories as to the probable origin of the thymus and of the epithelial rudiments in the cervical region, which I arrived at in the anatomical investigation of young turtles, and to which I have already drawn attention in a previous memoir ("Beiträge zur Kenntnis der Halsgegend bei Reptilicn: I. Anatomischer Teil," published in "Bijdragen tot de Dierkunde, uitgegeven door het Genootschap Natura Artis Magistra te Amsterdam,' 1880).--Anatomischer Anzeiger, viii. Jahrg., nos. 23 and 24, October 10, 1893, pp. 801-803.

Observations on the Karyokinetic Phenomena in the Cells of the Blastoderm of Teleosteans. By MM. E. Bataillon and R. KorHuer.

In a previous communication we have described the results of our researches upon the extension of the blastoderm on the surface of 